
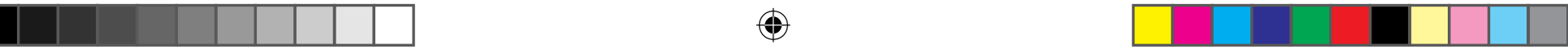

\title{
WARISAN TEMBIKAR TRADISIONAL MELAYU DI PAHANG
}

\author{
MOHD ZAMANI MOHD NOR PEAH * \\ NUBLI MUHAMMAD ** \\ HAMDZUN HARON *** \\ PHAOSAN JEWAE **** \\ zact73@gmail.com
}

\begin{abstract}
Abstrak
Kajian ini meneliti tentang sejarah dan perkembangan kegiatan pembuatan tembikar tradisional Tembeling yang dijalankan di Kampung Pasir Durian dan Temin Kraf di daerah Jerantut, Pahang. Kegiatan ini bermula di Kampung Pasir Durian sejak sekian lama manakala perusahaan di Temin Kraf pula merupakan satu kesinambungan terhadap kegiatan ini. Kajian terdahulu terhadap tembikar tradisional di Malaysia mendapati kegiatan ini disaingi dengan kewujudan perubahan cara pembuatan menggunakan teknik dan peralatan moden yang menyebabkan aktiviti pembuatan secara tradisional menggunakan tangan mulai terhakis. Pada masa yang sama jumlah pengiat semakin berkurangan dan tidak banyak kajian ilmiah yang menyentuh perkembangan kegiatan ini. Penyelidikan ini merupakan satu kajian kualitatif yang merakamkan secara deskriptif kegiatan tembikar tradisional Tembeling di negeri Pahang. Seramai 3 orang penggiat tembikar dari Kampung Pasir Durian dan Temin Kraf telah dipilih secara purposive sampling sebagai peserta kajian. Bagi mencapai objektif kajian, pengutipan data telah dilakukan melalui kaedah pemerhatian, temu bual dan analisis dokumen. Analisis data telah telah dibuat secara deskriptif dan interpretasi (Ragans, 2000). Dapatan kajian menunjukkan kegiatan penghasilan tembikar tradisional Tembeling di Kampung Pasir Durian semakin terancam kerana kebanyakan penggiat sudah tidak aktif atas faktor usia serta ketiadaan generasi pelapis yang berminat. Walau bagaimanapun, terdapat usaha daripada Temin Kraf yang meneruskan penghasilan dengan menggunakan teknologi moden.
\end{abstract}

Kata kunci: Warisan, Tembikar, Terenang, Tembeling, Teknologi

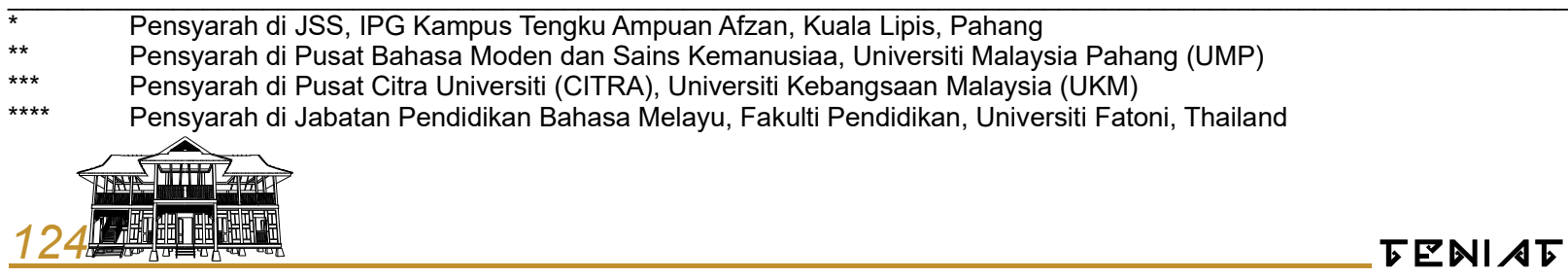



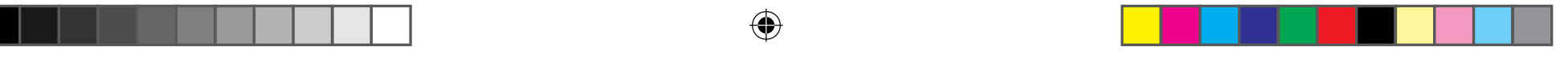

\begin{abstract}
This study examines the history and development of the traditional Tembeling pottery making in Kampung Pasir Durian and Temin Kraf in Jerantut, Pahang. The cultural practice had begun in Kampung Pasir Durian since a long time ago whereas the industry of Temin Kraf is an extension of the cultural activities. The previous studies on traditional pottery in Malaysia found that this cultural practice was threatened by the change in the way of modern equipment and techniques used that resulted in the decline of the traditional craftsmanship by. At the same time, there is a decrease in the number of activists and not many scientific studies touch on the development of these activities. This research is a qualitative study with descriptive records of Tembeling traditional pottery in Pahang. Three pottery makers from Kampung Pasir Durian and Temin Kraf were selected through purposive sampling as the participants in the research. To achieve the objectives of the study, data collection was done through observations, interviews and document analysis. Data analysis was done descriptively and interpretatively (Ragans, 2000). The findings show that traditional pottery production in Kampung Pasir Durian Tembeling is increasingly being threatened because most makers are not active due to the age factor and the young generations show no interest. However, there are efforts from Temin Craft to help continue the production by using modern technologies.
\end{abstract}

Keywords: Heritage, Pottery, Terenang, Tembelin, Technology

\begin{tabular}{ll}
\hline$*$ & Lecturer at JSS, IPG Kampus Tengku Ampuan Afzan, Kuala Lipis, Pahang \\
$* *$ & Lecturer at Centre of Modern Language and Science Humanities, Universiti Malaysia Pahang \\
$* * *$ & Lecturer at Centre of Citra University (CITRA), Universiti Kebangsaan Malaysia (UKM) \\
$* * * *$ & Lecturer at Department of Malay Language Education, Faculty of Education, Universty of Fatoni, Thailand
\end{tabular}



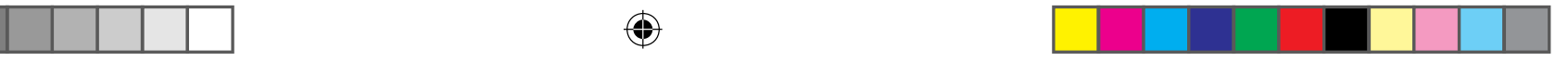

\subsection{Pengenalan}

Tembikar merupakan salah satu barangan kraf tradisional yang paling awal dihasilkan oleh manusia. la diperbuat dari tanah liat yang diproses, dibentuk dan dibakar serta disuaikan dengan fungsi yang dikehendaki. Di Semenanjung Malaysia sahaja kewujudan kegiatan tembikar tradisional hingga ke hari ini menjadi bukti kewujudan tamadun bangsa Melayu di Nusantara. Kajian lepas menunjukkan tiga negeri yang masih meneruskan kegiatan ini ialah Perak, Kelantan dan Pahang. Di negeri Pahang kewujudan awal tembikar tradisional boleh dikaitkan dengan Tun Seri Lanang dalam Sulalatus Salatin (1612) yang menyatakan :

"Barang maklumlah Duli yang Dipertuan, inilah banyak bilangan harta hamba sahaya patik itu yang disuratkan tiga hari tiga malam, pertama-tama harta patik itu talam tiada berbibir lagi pasu satu, dan bokor pecah atas Terenang Pahang. Sumbing satu, dan pinggan retak China satu, dan mangkuk retak satu, dan piring karang satu, dan periuk tembaga satu putus bibirnya, dan belanga Keling tembaga satu; dan budak tiga orang-seorang si Berkat namanya, berkayuh di buritan, lagi membawa pedang; Selamat seorang namanya, duduk menimba ruang, lagi membawa epok, lagi membawa pengudat."

Pernyataan ini menunjukkan bahawa tembikar merupakan barang dagangan utama yang dibawa dalam proses urusniaga para pedagang. Di samping itu, Tun Seri Lanang juga turut menyentuh mengenai kewujudan Terenang Pahang sebagai salah satu peralatan yang telah digunakan oleh orang Melayu sejak sekian lama. Peribahasa Melayu ada mengatakan " Hendaklah seperti tembikar, pecah satu pecah semuanya" yang bermaksud hendaklah hidup dalam muafakat; senang sama-sama senang, susah sama-sama susah. Melalui peribahasa Melayu ini, kita dapat membuat kesimpulan bahawa tembikar memainkan peranan yang penting dalam kehidupan orang Melayu pada masa lampau. Dewasa ini produk tembikar tradisional Pahang agak kurang menonjol jika dibandingkan dengan barangan tembikar dari negeri Perak terutamanya. Kegiatan ini tidak sepatutnya dibiarkan perlahan-lahan lenyap kerana ia akan membawa bersama hilangnya kemahiran, alat, bahan, teknik, reka bentuk, motif dan sebagainya yang menjadi warisan negeri Pahang.

Perusahaan tembikar tradisional di negeri Pahang merupakan satu warisan kraftangan yang semakin kurang mendapat perhatian umum berbanding tembikar dari Perak seperti Labu Sayong. Menurut Azmi et al. (2010) menyatakan perusahaan tembikar labuSayong terus berkembang dan mendapat tempat yang agak baik dalam kalangan masyarakat. Ini tidak berlaku pada kegiatan tembikar tradisional negeri Pahang yang kelihatan semakin perlahan perkembangannya. Situasi ini dapat dibuktikan berdasarkan beberapa kajian lepas yang terus menerus menjadikan kegiatan di Kampung Pasir Durian sebagai subjek utama kajian dan hanya menyentuh sedikit sahaja tentang perkembangan yang berlaku dengan merujuk pada Temin Kraf sebagai sebuah perusahaan tembikar tradisional Pahang. Penulisan oleh Salwa (2010) merupakan kajian kes terhadap perusahaan ini di 
Kampung Pasir Durian manakala Nurrul Izzah (2011) dan Zahirah Harun (2016) turut menjadikan kegiatan tembikar di Kampung Pasir Durian sebagai subjek utama dan hanya memberi sedikit sudut pandang terhadap perusahaan di Temin Kraf. Kajian ini penting bagi mengetahui mengetahui pewaris kemahiran kerja tangan ini selepas Kampung Pasir Durian kerana satu-satunya pengiat yang aktif iaitu Hajah Noriah sudah berhenti sepenuhnya pada tahun 2016. Objektif kajian ini adalah bertujuan untuk mengkaji perkembangan perusahaan tembikar tradisional Tembeling yang menjadi warisan negeri Pahang.

\subsection{Metodologi}

Penyelidikan ini adalah satu kajian kualitatif yang merakamkan secara deskriptif tembikar tradisional Tembeling yang dihasilkan di Kampung Pasir Durian dan Temin Kraf di Jerantut, Pahang. 3 orang pengiat tembikar dari Kampung Pasir Durian dan Temin Kraf telah dipilih secara purposive sampling sebagai peserta kajian. Kajian ini memfokuskan kepada aspek sejarah lokasi, komposisi tanah, teknik pembuatan, dekorasi permukaan, teknik pembakaran, fungsi, penerapan asas seni reka dan transformasi seni reka. Penyelidikan ini akan turut mengenal pasti cabaran dan halangan yang dihadapi oleh pembuat tembikar untuk terus memajukan perusahaan ini. di samping mengenalpasti usaha-usaha yang boleh dilakukan untuk meningkatkan produktiviti serta pasarannya bagi membolehkan tembikar ini setaraf penghasilannya dengan tembikar tradisional dari tempat lain. Kajian menggabungkan pemerian (deskriptif), analisis dan juga interpretasi untuk menganalisis data. Mengikut Ragans (2000) terdapat empat peringkat kajian kualitatif berkaitan dengan analisis seni visual iaitu :

i. Deskripsi atau pemerian

Memberi fokus utama terhadap sesuatu yang terdapat pada lakaran motif. Contohnya apa yang terdapat pada sesuatu motif seperti ukurannya termasuklah lebar dan tinggi. la adalah proses untuk mengenal dengan jelas bentuk format yang digunakan dan di mana digunakan.

ii. Analisis

Merupakan kajian dengan mendalam untuk setiap karya visual termasuk analisis untuk mengenali kandungan asas seni reka. la juga membuat analisis tentang prinsip rekaan seperti keseimbangan, harmoni, ulangan, kesatuan, kepelbagaian, rentak, kadar banding, arah dan pergerakan. 
iii. Interpretasi atau Penterjemahan

Membuat tanggapan, andaian, agakan, bayangan yang ada hubung kait dengan dapatan yang rasional terhadap motif. Dalam konteks, ini kita boleh membuat andaian tentang teknik yang digunakan, bahan yang digunakan emosi dalam menghasilkan iaitu emosi budaya pada masa itu. Pengalaman bagi menghasilkan dan kreativiti yang wujud.

iv. Judgement atau Penilaian

Membuat penilaian tentang keputusan yang terdapat dalam deskripsi, analisa dan interpretasi. Kesimpulannya boleh diolah dengan mengikut susunan dan format yang betul, tepat dan terperinci (Eric Fernie, 1989).

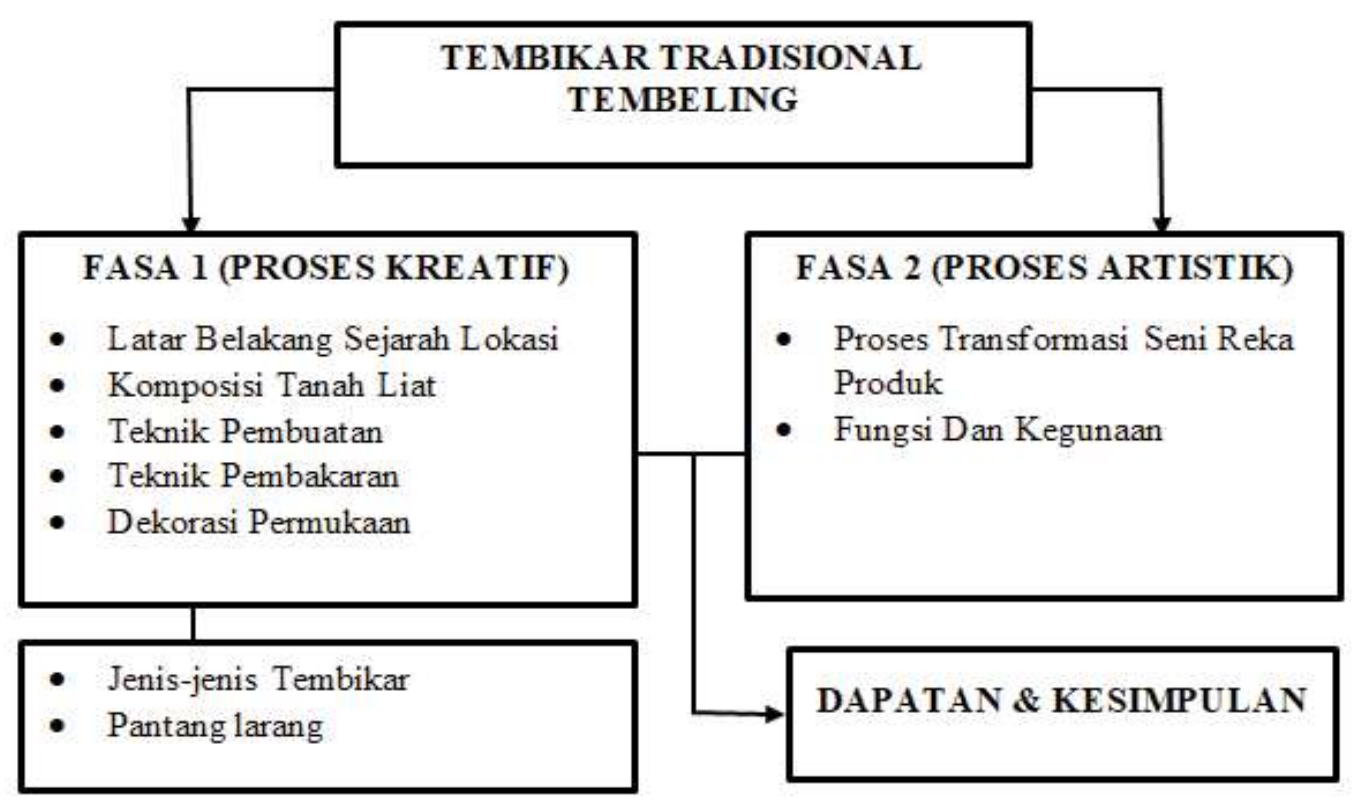

Rajah 1: Kerangka Kajian

Sumber: Adaptasi dari Fauziah (2006) dalam Salwa (2011) 


\subsection{Sejarah Tembikar Melayu}

Tembikar telah dikenalpasti wujud di Malaysia sejak beribu tahun dahulu. Bukti penemuan barangan tembikar dapat dirujuk pada dokumen penggalian arkeologi yang dilakukan di beberapa buah negeri di negara ini. Selain tembikar Terenang di Pahang, tembikar Sayong dan tembikar Mambong juga merupakan tembikar tradisi Melayu yang terdapat di Semenanjung Malaysia.

Di alam Melayu, tembikar berfungsi sebagai alat perkakasan di dapur untuk memasak dan menyimpan makanan serta minuman. Mengikut kepercayaan orang Melayu terdahulu, air yang disimpan dalam bekas tembikar menjadi lebih sejuk dan makanan yang dimasak dalam tembikar lebih enak dan mempunyai aroma tersendiri. Pembuatan tembikar oleh masyarakat terdahulu memaparkan kebijaksanaan dalam mencipta sesuatu yang bersesuaian dengan keperluan harian untuk melindungi dan memanjangkan hayat makanan atau minuman. Kepandaian ini juga menjadi suatu lambang kepada permulaan wujudnya sejarah sebuah bangsa yang bertamadun. Namun begitu adalah sukar untuk mengenalpasti sejak bila orang Melayu awal mula mencipta tembikar walaupun terdapat beberapa kajian terdahulu telah dibuat kerana menurut Azmi et al. (2010) kebanyakan tamadun umumnya tidak mempunyai catatan atau rekod yang sempurna tentang sejarah asal-usul terciptanya alat-alatan ini di tempat mereka.

Usaha mengkaji artifak seperti tembikar adalah bertujuan untuk memahami pembinaan budaya dan sejarah lepas ketamadunan sesuatu bangsa. Chia Ming Soon (1995) menyatakan kajian mengenai tembikar amat penting bagi ahli sejarah, ahli arkeologi dan ahli antropologi untuk memahami tentang sejarah, budaya dan kesenian silam dan menjadi rujukan tahap kemajuan dan ketamadunan sesuatu bangsa. Ini kerana sejarah ketamadunan manusia selalunya bermula dengan penciptaan alat-alatan asas yang diperbuat daripada tulang temulang atau tanah liat (Azmi Ariffin et al., 2010). Di negara ini aktiviti ekskavasi oleh sarjana-sarjana barat di gua-gua telah membawa kepada penemuan dan kajian terhadap tembikar primitif Melayu sejak awal kurun ke-20. Kajian-kajian oleh Ahli Arkeologi menyatakan sejarah kesenian tembikar di Malaysia telah bermula semenjak zaman prasejarah atau zaman neolitik berdasarkan penemuan di gua-gua, tepian sungai yang dihuni oleh manusia (Azmi Ariffin et al., 2010). Artifak tembikar ditemui di Gua Cha di Kelantan, Kuala Tembeling di Pahang, Bukit Wang Pisang, Bukit Tambun di Perak, Bukit Tengku Lembu di Perlis serta Gua Niah dan Gua Sireh di Sarawak (Siti Zainon, 1989; Shamsu Mohamed 2005). Walaupun terdapat pengaruh bentuk-bentuk tembikar daripada luar Tanah Melayu kira-kira sejak 1100 tahun masihi yang lampau terutamanya pengaruh daripada tembikar China tetapi penciptaan serta reka bentuk tembikar tradisional Melayu tetap terpelihara. Kajian oleh Leonard Wray, seorang kurator Muzium Perak pada tahun 1903, tentang kemunculan dan perkembangan kegiatan membuat tembikar di Perak menjelaskan dua fakta. Pertama, penemuan tembikar yang dihasilkan oleh orang Melayu pada zaman awal menunjukkan mereka sudah mula mencapai ketamadunan sejak awal lagi. Kedua, keunikan dan ketulenan hasil kerja tangan itu menunjukkan ia sebagai satu bentuk kesenian dan 

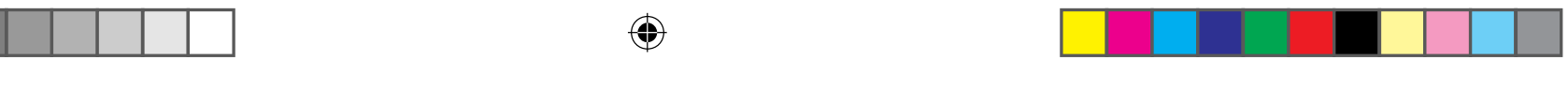

peralatan yang dicipta dan dimiliki oleh orang Melayu sepenuhnya tanpa sebarang pengaruh luar, sekurang-kurangnya bagi zaman yang awal sebelum kurun ke-20.

Di Malaysia, masih terdapat beberapa tempat yang meneruskan kegiatan seni tradisional ini seperti di Sayong (Perak), Mambong (Kelantan) dan Kuala Tembeling (Pahang) (Zahirah Harun, 2016). Perusahaan tembikar Tembeling merupakan satu-satunya warisan kesenian yang masih wujud dan bertahan sebagai identiti kraftangan negeri Pahang. Bagaimanapun pengkaji mendapati kegiatan di Kampung Pasir Durian tidaklah semeriah tahun-tahun awal 80 an di mana terdapat ramai pengiat yang masih aktif dinaungi oleh pihak koperasi yang ditubuh khas.

\subsection{Sejarah \& Latar Belakang}

Aktiviti penghasilan tembikar tradisional di negeri Pahang bermula di Kampung Pasir Durian yang berada di tebing Sungai Tembeling.yang merupakan salah satu sungai yang membentuk Sungai Pahang apabila bertemu dengan Sungai Jelai di Kuala Tembeling. Sungai Tembeling merupakan kawasan penempatan manusia yang telah dikesan semenjak zaman prasejarah (Ensiklopedia Sejarah dan Kebudayaan Melayu, 1999). Terdapat dua kaedah untuk sampai ke Kampung Pasir Durian iaitu dengan menaiki bot dari jeti Kuala Tembeling sekitar 10 minit atau melalui jalan darat yang memakan masa sekitar 45 minit iaitu kira-kira $37 \mathrm{~km}$ dari bandar Jerantut.

Kewujudan nama Kampung Pasir Durian dikatakan disebabkan oleh terdapat banyak pokok durian di situ. Terdapat cerita dari penduduk setempat yang menyatakan setiap orang yang menghilir atau mudik akan singgah untuk mengambil buah durian yang jatuh di atas pasir sungai, sehingga tempat persinggahan terkenal itu dengan nama Kampung Pasir Durian.

Oleh kerana penduduk di kampung ini amat giat menghasilkan tembikar, pihak British pada tahun 1919, telah merizabkan tanah seluas 2.4 hektar yang dikenali sebagai 'tanah miskin terletak kira-kira 3.25 dari kampung Pasir Durian. Tanah ini terletak di kawasan yang dikenali dengan nama Sungai Periuk yang bersempadan dengan sebatang sungai dan nama "periuk" itu pula berkaitan dengan kegiatan penduduk kampung yang membuat belanga. Tanah di kawasan ini dipercayai mengandungi sejenis tanah liat yang paling sesuai untuk membuat tembikar seperti Terenang, periuk dan belanga Tembeling. Ini berkemungkinan disebabkan oleh banjir pada tahun 1926 (banjir merah), 1931 dan 1970 yang telah banyak mengubah struktur dan keadaan kandungan tanah. Tanah di sini telah digunakan semenjak turun temurun sebelum dirizabkan oleh pihak British. Lawatan pengkaji ke tapak rizab tersebut mendapati laluan untuk mengambil tanah telah tertutup dengan belukar malah saiz tanah semakin mengecil kerana penduduk kampung telah menanam pokok getah atau pokok sawit di kawasan yang bersempadan. 

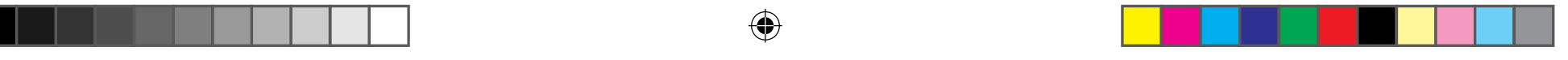

Peruntukan khas telah disalurkan oleh Kementerian Pembangunan Negara dan Luar Bandar sekitar awal tahun 80 an yang bertujuan untuk mengerakkan industri membuat tembikar di Kampung Pasir Durian dan berpotensi untuk berkembang. Pejabat Daerah Jerantut, Kemas, Jabatan Pembangunan Koperasi dan Perbadanan Kemajuan Kraftangan Malaysia cawangan negeri Pahang telah terlibat dengan penubuhan koperasi dan bengkel tanah liat yang dikenali dengan nama Projek Koperasi Industri Kampung Pasir Durian. Sebuah bengkel yang dilengkapi dengan kemudahan membuat tembikar telah dibina di atas tanah bilik mantan ketua kampung semasa itu iaitu, Tuan Haji Abdul Rahman bin Khatib Dollah. Kemudahan-kemudahan membuat tembikar di bengkel tersebut mendapat bantuan daripada Kementerian Negara dan Luar Bandar melalui Kemas terdiri daripada mesin membentuk, mesin pusing kuasa tangan, mesin pusing kuasa kaki, dapur, janakuasa elektrik dan almari.

Projek ini berjaya menyatukan para pengiat tembikar di sekitar Kampung Pasir Durian di bawah satu pengurusan. Keadaan ini memudahkan tembikar-tembikar yang dapat dipasarkan pada sasaran dan mendapat keuntungan yang lebih. Pasaran barangan ini ialah di Rumah Karyaneka Pahang (Kuala Lumpur), Balai Seni Visual Negara, Karyaneka Negeri (Kuantan), tempahan-tempahan tempatan, pelancong-pelancong dan permintaan individu. Barangan yang dihasilkan adalah seperti Terenang besar, Terenang kecil, belanga, periuk, buyung dan bekas habuk rokok. Pada awal penubuhan terdapat seramai 43 orang ahli, 11 orang ahli jawatankuasa dan seorang pengurus. Koperasi ini telah dirasmikan oleh Perdana Menteri ketika itu, Datuk Seri Dr. Mahathir Mohammad pada 5 April 1985.

Walau bagaimanapun hasil daripada tinjauan dan temubual yang dilakukan, koperasi ini didapati sudah tidak lagi beroperasi kerana tiada kesediaan dalam kalangan pengiat untuk berubah terutamanya daripada segi teknologi pembuatan terkini seperti penggunaan peralatan moden, dekorasi serta tatacara perniagaan yang lebih sistematik. Selain itu, faktor fungsi tembikar Tembeling yang semakin terhad dan terbatas berbanding alatan moden yang diperbuat daripada plastik turut menyumbang kepada kemerosotan penghasilan tembikar ini. Sikap para pengiat yang lebih selesa dengan cara pembuatan tradisional dan tiada usaha untuk membuat penyelidikan pembangunan dalam produk tembikar yang mereka buat juga menyumbang ke arah pengurangan jumlah pengeluaran dan juga pengiat. 


\subsection{Jenis-Jenis Tembikar Tradisional Tembeling}

Kajian oleh Salwa (2011) dan Zahirah (2016) menyatakan terdapat beberapa jenis tembikar yang dikategorikan sebagai tembikar Tembeling iaitu Terenang, belanga, perasapan, periuk tanah, bekas pembakar kuih dan buah delima. Setiap satu dari tembikar ini mempunyai fungsi tersendiri. Terenang merupakan produk yang paling dikenali dan boleh dianggap sebagai identiti produk tembikar tradisional negeri Pahang. Pengeluaran Terenang masih dilakukan hingga hari ini termasuklah belanga tetapi produk-produk lain sudah tiada permintaan malah reka bentuknya tidak disimpan oleh pengiat atau muzium.

Terenang merupakan bekas menyimpan air dan digunakan sebagai bekas simpanan air minuman, mandi bunga dan air penawar serta dikatakan boleh menyembuhkan penyakit jika meminum air darinya. Berdasarkan cerita dari Puan Noriah binti Mohd Ali salah seorang pengiat di Kampung Pasir Durian, nama Terenang berasal dari perkataan 'tunang'. Satu masa dahulu semasa upacara merisik dan meminang satu bekas tembikar kecil digunakan untuk meletakkan cincin pertunangan semasa adat istiadat perkahwinan di kampung tersebut. Maka tanah liat dibentuk seperti mangkuk kecil dan di hias indah untuk meletakkan cincin tersebut. Lama-kelamaan bekas tersebut di sebut terenang mengikut dialek masyarakat tempatan. Daripada bekas cincin yang kecil Terenang berubah fungsinya menjadi tempat menyimpan air apabila reka bentuknya di besarkan. Bentuk Terenang dikatakan dipengaruhi bentuk bekas tembaga dari Kelantan dan Terengganu. Bentuk leher Terenang yang cengkung dan bahagian badannya pula yang cembung dan serta berkaki membuatkan reka bentuk terenang nampak unik. Tafsiran ini selari dengan pernyataan Syed Ahmad Jamal (1979) yang mengatakan bahawa Terenang menyerupai bentuk logam.

Kamus Dewan Edisi Keempat mentakrifkan Terenang sebagai sejenis kendi air yang bertutup dan dibuat daripada tanah liat. The Encyclopedia of Malaysia Crafts and The Visual Arts (2007) menyatakan :

"...The Terenang has an elegant shape with unique propotions. It is beleived that the Terenang's shape is based on the brassware containers once made in Kelantan and still made in Terengganu. The Terenang's concave neck curves outwards, providing a contrast with the convex-shaped body and sharp-edged goot. Delicate flower motifs are arranged horizontally on the main body and vertically on the neck..." 


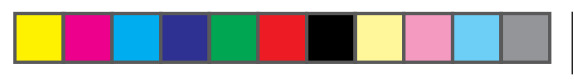

Selain Terenang, terdapat beberapa jenis lagi produk tembikar yang dikeluarkan iaitu belanga, bekas perasapan, periuk tanah, bekas pembakar kuih dan buah delima.

Kepelbagaian jenis reka bentuk tembikar ini menunjukkan kebijaksanaan orang-orang dahulu memanafaatkan tanah untuk menjadikan alat yang berfungsi memenuhi keperluan harian.

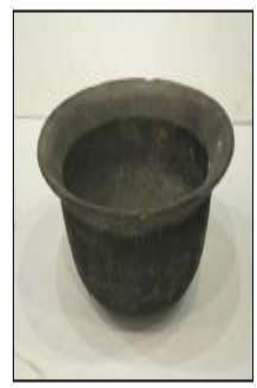

(i)

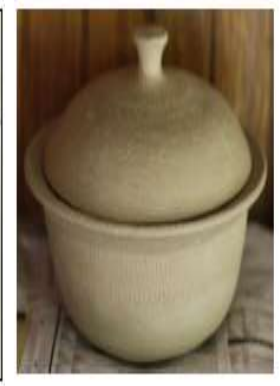

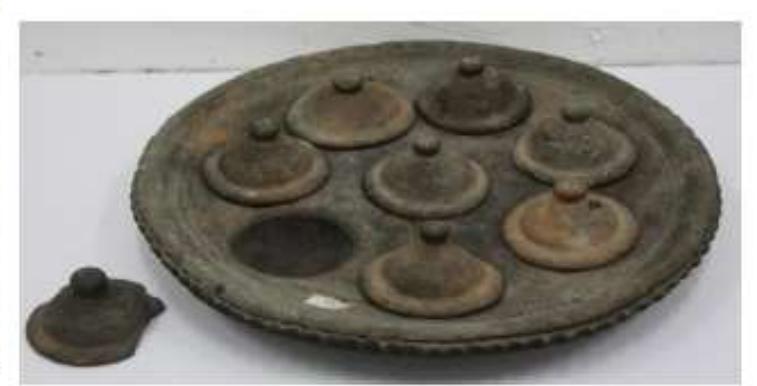

(ii)

Rajah 2: (i) Belanga (ii) Bekas Pembakar Kuih Koleksi Muzium Sultan Abu Bakar, Pekan

(Sumber: Zahirah, 2016)

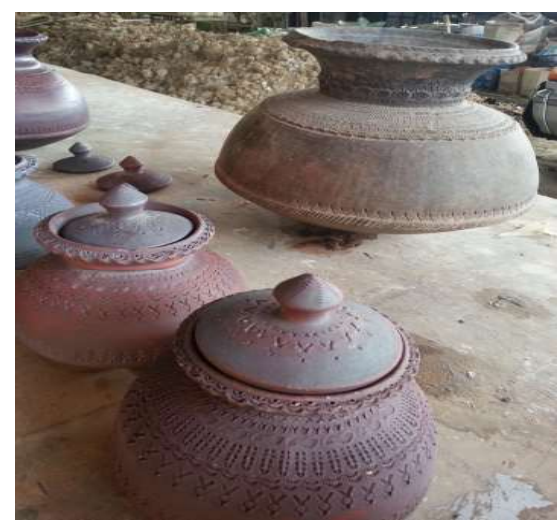

(iii)

Rajah 3: Terenang

(Sumber: Temin Kraf, 2016) 

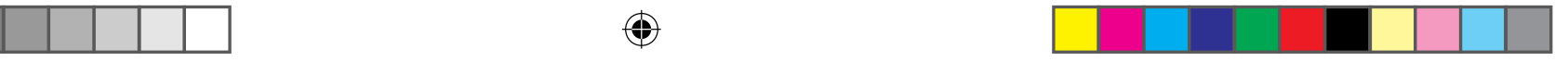

\subsection{Komposisi Tanah Liat}

Kajian oleh Zainal dan Oskar (2006) menyatakan bahawa penghasilan tembikar tradisional tempatan adalah berasaskan sumber tanah liat iaitu terracotta. Ivor H.H Evans (1922) pula menyatakan tanah liat yang digunakan untuk menghasilkan tembikar adalah berwarna kuning sebelum dibakar. Salwa (2011) menyatakan bahawa ciri-ciri tanah yang baik untuk menghasilkan tembikar Tembeling ialah tanah yang apabila terkena mata cangkul akan kelihatan berkilat, tanah yang digali dengan cok seolah-olah menarik ketika ditarik naik, tanah tersebut akan melekat semasa dipicit dan tidak berderai apabila dikepal atau digenggam. Dapatan ini hampir sama dengan pandangan Ibrahim dan Sahaimi (2005) yang menyatakan tanah liat Tembeling yang digunakan oleh penduduk setempat tersebut biasanya berwarna coklat kekuningan, mudah berderai apabila dipicit dalam proses pembuatan Terenang.

Proses mengambil tanah liat akan bermula dari waktu pagi hingga ke petang. Proses bermula dengan mengali lubang menggunakan cangkul atau penggali sedalam 1 hingga 2 meter. Tugasan ini hanya dilakukan oleh orang lelaki sahaja dan sangat mahir mengenali jenis tanah yang dikehendaki. Terdapat dua jenis iaitu lubang yang digali iaitu lubang yang memanjang melintang dan lubang dalam ke bawah seperti telaga. Semasa proses pengalian juga pengasingan batu, pasir, kayu atau bendasing juga dilakukan. Tugas-tugas lain seperti pengumpulan, pembersihan, pengadunan dan sebagainya dilakukan oleh wanita.

Hanya tanah liat tulen sahaja akan diisikan dalam ambung (bakul yang digalas di belakang badan) untuk dibawa balik bagi proses seterusnya. Tanah liat akan direndam dalam takung yang diperbuat sama ada dari kayu pulai atau tin sehingga menjadi lembut. Tanah liat yang lembut akan ditumbuk menggunakan antan dan papan alas, kebiasaanya diperbuat dari kayu tualang. Selain itu pengusaha juga mengunakan lesung indik dan menumbuk tanah liat kering semasa kegiatan bergerak di bengkel. Tanah yang lumat akan diayak lalu dibancuh dengan air supaya lembut dan memudahkan ia dibentuk.

Setelah kegiatan di bengkel penghasilan tembikar Kampung Pasir Durian terhenti, kawasan tanah rizab ini juga telah terbiar dan ditumbuhi belukar tebal serta sukar untuk dilawati. Temin Kraf tidak menggunakan tanah rizab ini kerana jarak yang tidak praktikal dan untuk menjimatkan kos. Tanah telah dibeli dari pihak luar seperti dari Beranang di Selangor. Apabila permintaan terhadap tembikar semakin tinggi, Temin Kraf telah memproses tanah yang diambil dari sekitar bengkel bagi menjimatkan kos pengeluaran. Kualiti tanah yang digunakan di Temin Kraf adalah tidak sama seperti yang terdapat di Kampung Pasir Durian. Tanah ini perlu diproses dengan kaedah moden dengan mencampurkan ia dengan beberapa jenis sebatian seperti silika bagi mendapatkan jasad tembikar menggunakan teknik acuan tuang. Proses tanah bermula dengan tanah yang telah digali dimasukkan ke dalam mesin blunger untuk menghancurkan tanah dan menyebatikan ia dengan sebatian tertentu. Tanah liat akan berubah dalam bentuk cairan slip likat yang memudahkan ia dituang ke dalam acuan. 


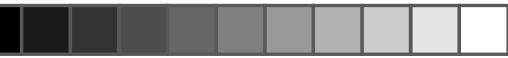

\subsection{Pantang Larang Dan Kepercayaan}

Pengiat-pengiat tembikar di Kampung Pasir Durian mempunyai pantang larang yang mesti dipatuhi ketika mengambil tanah liat. Setiap lelaki yang mengambil tanah liat perlu memakai gelang seperti tangkal yang diperbuat daripada akar kayu yang dikenali sebagai ulan. Ketika proses pengalian lubang, individu yang terlibat tidak dibenarkan membuang angin (kentut) kerana dikhuatiri tidak akan menemui tanah yang dikehendaki. Dipercayai mereka yang tidak patuh pada pantang larang ini selalunya tidak akan berjumpa dengan jenis tanah yang dicari.

Individu-individu yang terlibat mengambil tanah perlu mempunyai niat yang baik, jika mereka mempunyai niat yang jahat seperti mencuri tanah di kawasan tersebut biasanya tidak akan menemui tanah liat yang dikehendaki walau mengali sedalam mana pun. Tanah liat juga perlu diambil oleh ahli sahaja iaitu mereka yang terlibat dengan penghasilan tembikar Tembeling ini sahaja. Jika bukan ahli atau orang luar yang mengambil tanah tersebut, dipercayai tembikar akan hancur semasa ataupun selepas proses pembakaran. Ketika proses pembakaran juga dilarang membuang angin kerana ia mungkin akan menyebabkan tembikar akan bocor ketika proses pembakaran. Bagaimanapun pantang larang dan kepercayaan ini semakin dilupakan apabila proses penghasilan tembikar semakin menerima teknologi moden malah tiada keperluan untuk diamalkan di Temin Kraf.

\subsection{Teknik Pembuatan Tembikar}

Proses penghasilan tembikar secara tradisional bermula dengan proses pencarian tanah yang didapatkan melalui proses pengalian tanah di tanah rizab. Tanah yang sudah lumat ditumbuk dan serbuk tanah liat yang siap dibancuh akan diuli seperti menguli tepung. Tanah liat yang lembut akan ditempa dengan tangan menggunakan badang beralaskan papan alas.

Secara keseluruhannya pembuatan tembikar tradisional menggunakan teknik picit cubit. Teknik picitcubit merupakan kaedah tradisional yang digunakan dalam mendapatkan bentuk tembikar. Teknik ini merupakan teknik utama yang digunakan untuk membina dinding belanga. Hamdzun dan Narimah (2013) menyatakan kesemua proses pembuatan tembikar tradisional seperti Terenang, labu Sayong, tembikar Mambong menggunakan teknik ini. Kaedah ini memerlukan pinggan atau meja putar untuk memudahkan proses membina dinding tembikar. Kemahiran menggunakan kedua belah tangan berperanan untuk membentuk dan memusingkan pinggan. Penepek atau sudip kayu dipraktikkan bagi menepek permukaan dinding dengan tujuan untuk memadat dan meratakan permukaan luar dinding tembikar yang dilaksanakan setelah proses membentuk siap. 
Anak batu berbentuk lesung kecil akan digunakan dalam proses penerapan di bahagian tapak dengan menolak secara perlahan dari bahagian dalam supaya ia melengkung ke bawah (Ibrahim dan Sahaimi, 2005). Proses menguka pula bertujuan untuk mengikis bahagian dalam dengan menggunakan kukur. Bagi mendapatkan permukaan tembikar yang berkilat, batu sungai akan digosokkan pada permukaan.

Penghasilan tembikar Tembeling secara moden bergantung sepenuhnya dengan acuan tuang. Acuan tuang merupakan bekas yang dihasilkan dari Plaster of Paris dan digunakan untuk membentuk tembikar dengan menuang slip atau cecair tanah ke dalamnya. Penggunaan acuan tuang membolehkan tembikar dihasilkan dengan cepat pada jumlah yang banyak. Bagaimanapun di Temin Kraf pengeluaran tembikar Tembeling lebih kepada penghasilan Terenang. Terenang dihasilkan dengan pelbagai saiz dan fungsi bagi memenuhi keperluan dan permintan. Berdasarkan pemerhatian pengkaji pengeluaran produk-produk selain Terenang seperti belanga, labu, perasapan tidak dibuat kecuali kendi. Ini mungkin disebabkan kendi dihasilkan menggunakan acuan Terenang dan ditambah muncung menggunakan kemahiran tangan.

\subsection{Dekorasi Permukaan}

Tembikar tradisional Tembeling seperti Terenang dihiasi dengan motif-motif tradisional tempatan untuk menonjolkan identiti tempat asal pembuatannya. Salwa (2011) telah menemukan 30 jenis motif tetapi hanya 21 motif atau bunga yang telah dikenalpasti namanya. Jadual di bawah menunjukkan motif dekorasi permukaan Terenang pada setiap bahagiannya:

Jadual 2: Motif yang digunakan pada hiasan bahagian Tembikar Tradisional Tembeling (Terenang) Sumber: Salwa Ayob (2011)

\begin{tabular}{|c|c|c|}
\hline Bil & Bahagian & Motif \\
\hline 1. & Penutup & $\begin{array}{c}\text { Bunga Sambar } \\
\text { Bunga Kipas }\end{array}$ \\
\hline 2. & Bibir & $\begin{array}{l}\text { Picit Penyek } \\
\text { Balung Kuku }\end{array}$ \\
\hline 3. & Birai & $\begin{array}{c}\text { Bunga Kelopak } \\
\text { Alur Nibong }\end{array}$ \\
\hline
\end{tabular}



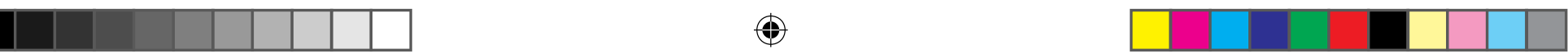

\begin{tabular}{|c|c|c|}
\hline 4. & Leher & Pucuk Rebung (3 garis) \\
& & Potong Wajik \\
& & Titik \\
\hline 5. & Dada & Pucuk Rebung \\
& & Bunga Padi \\
& & Belalang Secucuk \\
& & Potong Wajik \\
& & Bunga Sambas \\
& & Bunga Kelopak \\
\hline 6. & Taliair & Alur Nibong Berselang Pecah 4 \\
\hline 7. & Bontot & Bulan Sabit \\
\hline
\end{tabular}

Motif yang menghasilkan corak pada permukaan tembikar Tembeling adalah hasil daripada hujung kayu pengecap atau kayu tera yang diukir. Kayu ini diperbuat dari kayu-kayu yang tahan lama seperti kayu hanyut yang dijumpai di tepi sungai. Proses mengecap ini memerlukan pengalaman dan kemahiran bagi memastikan motif yang dicap mengelilingi badan tembikar supaya tidak akan bertindih seperti yang diperhatikanTerenang. Selain daripada kaedah terapan, keunikan yang ada pada dekorasi permukaan tembikar Tembeling seperti Terenang dikenali sebagai Gigi Jawa dan Tali Air. Hiasan Gigi Jawa yang menjadi identiti Terenang kebiasaannya dapat dilihat di bahagian luar mulut yang kelihatan seperti lekuk-lekuk yang terhasil dari batang rod. Tali air pula menjadi pemisah antara bahagian-bahagian di permukaan Terenang. 

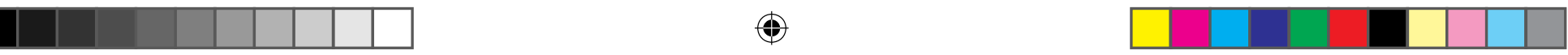

Tembikar Tembeling tidak seperti Labu Sayong yang beridentitikan warna hitam. MenurutAbdul Rahim et al. (2013) teknik penghitaman Labu Sayong yang biasa dilakukan, sama ada cara tradisional atau moden, adalah dengan mengeluarkan Labu Sayong dari ruang pembakaran, satu persatu setelah pembakaran mencapai suhu matang, pada $850^{\circ} \mathrm{C}$ ke $900^{\circ} \mathrm{C}$ dan dimasukkan ke dalam sekam padi. Zahirah (2016) menyatakan di Kuala Tembeling tanah liat hitam yang digunakan akan menghasilkan tembikar yang bewarna hitam atau keadaan kayu yang digunakan untuk membakar tembikar turut menyumbang kepada keadaan fizikal tembikar selepas bakar. Terenang kebanyakkannya beridentitikan warna coklat seperti warna bahan asalnya.

\subsection{Teknik Pembakaran}

Teknik pembakaran tradisional dipraktikkan dalam proses pembakaran tembikar Tembeling mengunakan kayu yang sesuai seperti dahan-dahan kayu yang cukup kering sebesar lengan kanakkanak yang dipotong mengikut saiz objek yang akan dibakar. Daun kelapa kering diletakkan di atas tanah dan kayu akan disusun di atasnya dalam bentuk empat segi bertindih-tindih dan berselangseli. Tembikar yang akan dibakar pula akan diletakkan di tengah-tengah susunan kayu tersebut.

Pembakaran kebiasaannya akan dimulakan dengan membakar daun kelapa. Api akan dibiarkan marak sehingga kayu-kayu hangus menghasilkan bara. Bara akan diketepikan supaya tidak terkena pada tembikar untuk mengelakkan tompok-tompok hitam terhasil pada dinding tembikar. Tembikar akan dibiarkan sejuk secara semulajadi apabila pembakaran sudah selesai dan akan disimpan sebelum dipasarkan.

Kaedah pembakaran menggunakan gok atau tanur juga digunakan untuk membakar tembikar. Gok dibina daripada batu-bata dan proses pembakaran menggunakan kayu. Di kawasan ini, pengkaji mendapati terdapat gok-gok yang dibina telah terbiar dan tidak digunakan lagi. Selain itu, pengusaha tembikar dari Kampung Pasir Durian iaitu Hajah Noriah akan mendapatkan bantuan Temin Kraf bagi tujuan pembakaran menggunakan tanur gas. 


\subsection{Transformasi Seni Reka Produk}

Perubahan masa telah mempengaruhi keperluan manusia yang menyebabkan produk tembikar tradisional turut berubah untuk kekal relevan dengan kehendak semasa. Tembikar tradisional seperti Terenang dan belanga yang dihasilkan di Kampung Pasir Durian secara keseluruhannya masih mengekalkan reka bentuk asal. Bagaimanapun Temin Kraf juga telah mempelbagaikan fungsi, reka bentuk dan reka corak tembikar seperti Terenang. Proses pembuatan yang dipraktikkan juga tidak lagi mengekalkan cara tradisional keseluruhannya. Penggunaan teknologi pembuatan secara moden disesuaikan bagi memenuhi permintaan pasaran dan tuntutan masa seperti mempelbagai saiz Terenang dengan menggunakan kaedah penghasilan teknik acuan tuang. Acuan tersebut dihasilkan daripada Plaster of Paris dan penggunaan acuan ini dapat menyingkat tempoh masa pembuatannya serta tembikar Terenang ini dapat dihasilkan dalam jumlah yang lebih banyak. Namun demikian, daripada aspek dekorasi dan penerapan motif pula, pihak Temin Kraf masih lagi mengekalkan gaya tradisional seperti yang dibuat di Kampung Pasir Durian.

\subsection{Fungsi Dan Kegunaan}

Tujuan penghasilan tembikar adalah sebagai produk untuk keperluan utiliti harian masyarakat setempat. Asas rupa tembikar tradisonal Tembeling dicipta oleh usaha kreatif yang menekankan aspek fungsi dan penggunaan, tetapi ia juga menyerap unsur-unsur persekitaran dan juga menekankan genius tempatan. Terenang digunakan untuk tujuan perubatan tradisional seperti dalam upacara jampi serapah. Terenang menjadi mengisi air mawar asli sebagai ubat penawar. Selain itu ia digunakan untuk mengangkut serta menyimpan air. Air yang dimasukkan ke dalam Terenang, dipercayai akan sentiasa sejuk dan berbau wangi.

Belanga berfungsi sebagai bekas yang digunakan untuk memasak makanan seperti gulai, lauk ikan dan sayuran. Memasak di dalam belanga dikatakan lebih sedap dari memasak di dalam periuk dari bahan lain. Belanga dihasilkan dalam saiz kecil dan dan saiz besar untuk kesesuaian jumlah masakan.

Bekas perasapan atau tempat bara digunakan untuk tujuan membakar kemenyan bagi upacara tertentu seperti perubatan tradisional. Dalam perubatan tradisional seperti bomoh dan pawang, amalan menggunakan kemenyan adalah menjadi bahantara utama untuk memanggil semangat makhluk halus. Kemenyan dibakar dan diperasapkan di dalam bekas tembikar yang di panggil perasapan atau tempat bara. 

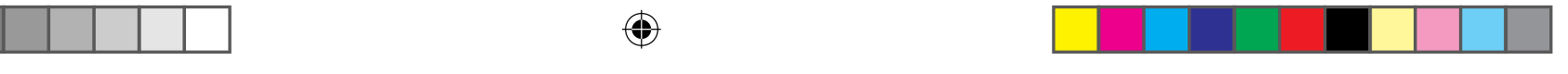

Periuk tanah ini di gunakan untuk merebus akar kayu sebagai pengubatan tradisional dan adakalanya untuk memasak nasi jika ketiadaan periuk lain. Bahagian bawah periuk tanah lebih nipis berbanding belanga kerana fungsinya lebih kepada untuk merebus sahaja. Bekas pembakar kuih tidak lagi dihasilkan kini. Bekas pembakar kuih yang ada hanya terdapat di Muzium Sultan Abu Bakar, Pekan. Bekas ini mempunyai lapan lubang acuan kuih dan mempunyai penutup bagi setiap lubang acuan tersebut. la mempunyai ukur lilit lapan belas inci dan tidak ada hiasan motif.

Buah delima pula juga bekas menyimpan air untuk kegunaan minuman seperti Terenang. la juga mempunyai cawan untuk minum air dari tembikar buah delima dan piring kecil sebagai pengalas. la di panggil buah delima kerana bentuknya yang seakan buah delima. Tembikar buah delima dihasilkan oleh pembuat tembikar di Ulu Tembeling satu masa dulu. Maklumat mengenai tembikar buah delima hanya terdapat dalam penulisan Evans sahaja.

Pada masa kini fungsi asal tembikar tradisonal ini semakin terpinggir dan dilupakan kerana wujud persaingan daripada produk moden yang dihasilkan seperti botol plastik, besen dan sebagainya di pasaran. Produk-produk ini lebih praktikal dan menarik dari segi reka bentuk yang memenuhi gaya hidup moden. Temin Kraf telah berusaha melestarikan kepelbagaian teknik dan pendekatan dalam penghasilan tembikar terutamanya dari segi proses penghasilan, fungsi, reka bentuk dan reka corak. Usaha ini telah melalui proses pemodenan teknologi bagi meyesuaikannya dengan permintaan semasa. Tembikar tradisional yang dihasilkan di Temin Kraf kebanyakkannya menjadi cenderamata dan barang perhiasan bagi memenuhi permintaan pengguna.

\subsection{Tokoh Tembikar}

Di dalam kajian lepas menamakan sejumlah besar nama-nama yang mengusahakan tembikar tradisional Tembeling sekitar 21 orang (Salwa Ayob, 2011) tetapi hanya dua individu yang mendapat pengiktiran dari Kraftangan Malaysia. Tokoh-tokoh tersebut ialah Puan Hajah Manja Ali (Perbadanan Kraftangan Malaysia, 2007) dan Puan Noriah binti Mohd Ali yang telah diiktiraf sebagai Adiguru Kraf Tembikar Tembeling oleh pihak Kraftangan Malaysia. Kemahiran membuat tembikar Tembeling seperti Terenang menyebabkan mereka sering menerima jemputan demonstrasi dan tempahan dari pelbagai pihak sama ada dari badan kerajaan ataupun persendirian. Bagaimanapun Hajah Manja Ali sudah lama meninggal dunia, manakala Puan Noriah pula sudah tidak aktif menghasilkan tembikar selepas tahun 2015 kerana faktor usia dan kesihatan. Usaha kedua-dua tokoh ini masih diteruskan oleh pihak Temin Kraf melalui penjualan produk, pelbagai latihan dan demonstarasi yang didedahkan kepada masyarakat. Ketiadaan generasi pelapis baru terutama dari Kampung Pasir Durian dikhuatiri akan menyebabkan tembikar Tembeling hanya tinggal nama. Pelapis terkini selepas Hajah Noriah ialah Encik Muhamad bin Zakaria yang gigih mengerakkan Temin Kraf. 

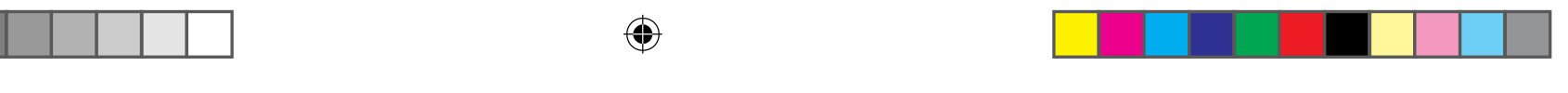

\subsection{Kesimpulan}

Kegiatan penghasilan tembikar Tembeling di Kampung Pasir Durian semakin suram jika dibandingkan dengan kegiatan di negeri Perak yang berkembang dengan baik dan mendapat sambutan yang mengalakkan (Azmi Arifin et al., 2010). Ini disebabkan oleh faktor umur yang sudah lanjut bagi pengiat-pengiat awal dan masalah kesihatan. Selain itu tiada pelapis-pelapis daripada generasi muda yang berminat untuk memberanikan diri menceburi bidang ini. Kemerosotan permintaan daripada masyarakat yang disebabkan oleh persaingan daripada peralatan moden yang lebih praktikal dan mudah dengan gaya hidup moden hari ini. Ditambah dengan fungsi tembikar sebagai barang utiliti di kalangan masyarakat juga kurang kelihatan. Situasi ini berada pada peringkat yang sangat membimbangkan kerana ia akan menyebabkan kegiatan ini pupus seperti yang berlaku pada kegiatan tembikar tradisonal di utara Semenanjung Malaysia. Sekiranya ini berlaku, maka hilanglah khazanah yang menjadi warisan negeri Pahang. Perkara ini telah disentuh oleh Salwa (2011) yang mendapati hanya terdapat enam orang sahaja yang masih menjayakan kegiatan ini tetapi kajian oleh Zahirah (2015) menyatakan hanya tinggal seorang sahaja yang masih aktif menjalankan aktiviti ini iaitu Hajah Noriah yang kini semakin berusia. Kajian ini pula mengesahkan kegiatan di Kampung Pasir Durian sudah terhenti sepenuhnya, malah Hajah Noriah sudah bersara atas faktor umur dan kesihatan.

Kegiatan penghasilan tembikar di Temin Kraf telah memberikan harapan kepada aktiviti tembikar tradisional Tembeling ini untuk terus dilestarikan. Temin Kraf menjadi perusahaan tunggal yang meneruskan kegiatan pembuatan tembikar di Pahang. Perusahaan sehingga hari ini masih digerakkan oleh dua invidu, iaitu Encik Muhammad dan Encik Zainal. Salah seorang pengiat ini berasal dari Kampung Pasir Durian. Temin Kraf berada dalam Kampung Temin yang terletak 10 kilometer dari pusat bandar Jerantut. Kemudahan-kemudahan di Temin Kraf mendapat bantuan daripada pihak kerajaan yang menyediakan tapak seluas sekitar 2 ekar yang dilengkapi bengkel dan bilik pameran. Bengkel tersebut juga dilengkapi alatan-alatan moden penghasilan tembikar.

Peredaran masa telah menjadikan fungsi tembikar tradisional semakin terhad mengikut keperluan masyarakat. Pihak Temin Kraf telah berani mengubah fungsi tembikar misalnya Terenang menjadi cenderamata dengan mempelbagaikan saiznya. Bagi memastikan tembikar Tembeling dapat dihasilkan secara massa atau bersaiz industri, teknik acuan telah digunakan sepenuhnya dalam proses penghasilan tembikar. Kajian ini mendapati bahawa teknologi moden menggunakan mesin telah dilaksanakan dengan jayanya dalam membuat tembikar tradisional di Temin Kraf tetapi pada masa yang sama terdapat juga bahagian yang memerlukan pembuatan secara manual menggunakan tangan. Ini menunjukkan bahawa di samping mengekalkan cara lama dalam teknologi, pemodenan juga memberikan sumbangan yang besar dalam aspek saintifik dan peralatan yang digunakan. 
Teknologi yang digunakan juga secara tidak langsung menyumbang kepada proses pembuatan yang lebih cekap dan akan meningkatkan produktiviti tembikar tradisional. Tajul et al. (2011) menyatakan pembangunan perkembangan budaya bermula dari proses penghasilan yang mudah hingga melibatkan penggunaan teknologi adalah mencerminkan kebijaksanaan pengusaha tembikar tradisional. Perkembangan ini telah membuktikan bahawa bakat dan kemahiran dalam kalangan pengiat yang mengaitkan pelbagai proses menggunakan teknologi telah menyumbang kepada kelestarian kegiatan pembuatan tembikar di Malaysia pada keseluruhannya.

\section{Rujukan}

A. Rahman, M.K. (1997). Hoabinh Di Pahang dlm Pembangunan Arkeologi Pelancongan Negeri

Pahang. Pahang: Lembaga Muzium Negeri Pahang, Pekan

Adiguru Kraf Master Craftsperson. (2007). Penerbit Kemajuan Kraftangan Malaysia

Ahmad, Z.A., Jamaludin, A.R., Sulaiman, M.A. (2014). Seni Tembikar. Pulau Pinang: Penerbit Universiti Sains Malaysia.

Ali, Z. (1989). Seni dan Seniman Esei-esei Seni Halus. Kuala Lumpur: Dewan Bahasa dan Pustaka.

Arifin, A., Abdul Rahman, M. L. \& Masron, T. (2010). Warisan Tembikar Labu Sayong di Kuala Kangsar, Perak: Sejarah, Perkembangan dan Masa Depan. Sari - International Journal of the Malay World and Civilisation: UKM

Ayob, S. (2011). Kesinambungan Perubahan Pemerian Jasad dan Rupa Tembikar Pra Sejarah kepada Tembikar Tradisi Melayu: USM.

Darus, I., Abdul Manaf, S.(2005). Tembikar Tradisional. Kuala Lumpur: Perbadanan Kemajuan Kraftangan Malaysia.

Ensiklopedia Sejarah dan Kebudayaan Melayu. (1999). Kuala Lumpur: Dewan Bahasa dan Pustaka

Fernie, E., (1995). Art History and Its Methods: A Critical Anthology. Phaidon Press Ltd., London.

Glosari Budaya Malaysia: Seni Tembikar.(1992). Kuala Lumpur. Dewan Bahasa dan Pustaka

H. N. Evans. (1922). The Potting Industry at Kuala Tembeling. F.M.S 9(4), 259-262

Harun, H., Abd. Mutalib, N. (2012). Aspek Estetika Labu Acu Malim. Jurnal Pengajian Umum Asia Tenggara: UKM 
Harun, H., Abd. Mutalib, N. (2013). Technology and Production Process of Malay Traditional Heritage Pottery in Malaysia. Jurnal Teknologi: UKM

Harun, H., Yusof, N.A., Mohammad Noh, L.M., Abd Mutalib, N. (2013). Technology and Production Process of Malay Traditional Heritage Pottery. Jurnal Teknologi. 20: hlm 85-88

Harun, Z. (2016). Keindahan Tembikar Melayu Tradisional Kampung Pasir Durian. Tesis Doktor Falsafah. Universiti Kebangsaan Malaysia, Bangi.

Harun, Z., Awang, N.N., Abdul Hadi, H. dan Muhammad, A. (2015). The Characterization of Kuala Tembeling Clay Pottery: Form And Cultural Function

Ismail, S.Z. (1986). Rekabentuk kraftangan Melayu tradisi. Kuala Lumpur: Dewan Bahasa dan Pustaka.

Jalil, A. R., Hassan, O.H., Md Zainuddin, N., Haron, H. (2013). Innovation of Blackening Labu Sayong. Jurnal Teknologi: UTM

Jamal, S.A.(1997). Rupa dan Jiwa. Kuala Lumpur: Penerbit Universiti Malaya.

Mohamad, S. (2005). The Malay pottery in Malaysia. Asia Ceramics Network Conference. Seoul, South Korea.12-18 January.

Mohd Johari, N.I. (2011). Seni Tembikar Tradisional Terenang Pahang Tradisi Dan Perubahannya. Tesis Sarjana. Universiti Pendidikan Sultan Idris, Tanjong Malim.

Ragans, R. (2000). Art Talk. New York: Glencoe/McGraw-Hill.

Said, T.S., Ramli, H., Sedon, M.H. (2011). Local Genius of Mambong Pottery in Kelantan, Malaysia. International Journal of Humanities and Social Science, 1(21): 147-155.

Soon, C.M. (1995). Indigenous prehistoric pottery and technology in Peninsular Malaysia. Malaysian Museums Journal: 155-183.

Zakaria, Z., Hassan, O.H. (2006). Pembangunan Jasad Terracotta Bagi Pengusahaan Seramik Di Negeri Pahang: UiTM 